\title{
ANALISIS KESESUAIAN DAN DAYA DUKUNG WISATA BAHARI DI PULAU MANGKIAN TAMAN WISATA PERAIRAN KEPULAUAN ANAMBAS
}

\section{ANALYSIS OF SUISTABILITY AND CARRYING CAPACITY OF MARINE TOURISM IN MANGKIAN ISLAND THE ANAMBAS ISLANDS MARINE TOURISM PARK}

\author{
Yuwanda Ilham ${ }^{1}$, Yusni Ikhwan Siregar ${ }^{1}$, Deni Efizon ${ }^{1}$ \\ ${ }^{1}$ Kekhususan Manajemen Sumberdaya Perairan Magister Ilmu Kelautan, Fakultas Perikanan dan \\ Kelautan, Universitas Riau, Jl. HR Soebrantas Km 12,5 Simpang Baru, Panam-Pekanbaru Indonsia \\ 28293 \\ Correspondence Author: yuwan39psdp@gmail.com
}

AR TICLE INFO

Submitted: 03 April 2018

Revised : 14 Mei2018

Approved: 20 Juni 2018
Kata kunci :

Wisata Bahari, Daya Dukung, Kesesuaian, Pulau Mangkian
Abstract

This study aims to determine the suistability and carrying capacity of marine tourism in Mangkian island of the Anambas Islands Marine Tourism Park. The survey was conducted in Mangkian Island, Batu Belah Village, East Siantan District, July to September 2017. Environmental parameters of coral cover (life form), and some aquatic biota strongly support marine tourism activities in this area. The results showed that The level of suitability of maritime tourism is at IKW value for coastal tourism category is very suitable, category diving tour accordingly, and snorkeling tour category according to conditional. The carrying capacity of the area in every tourism activity that is beach tourism 101 people / day, dive tourism 123 people / day and snorkeling tourism is recommended need rehabilitation first. Public perceptions on the management and development of marine tourism, especially in the ecological, economic and sociocultural aspects of local communities.

Abstrak

Penelitian ini bertujuan untuk mengetahu kesesuaian dan daya dukung wisata bahari di Pulau Mangkian Taman Wisata Perairan Kepulauan Anambas. Survei dilakukan di Pulau Mangkian, Desa Batu Belah, Kecamatan Siantan Timur Juli s.d September 2017. Parameter lingkungan, tutupan karang (life form), dan beberapa biota perairan sangat mendukung kegiatan wisata bahari di daerah ini. Hasil penelitian meneunjukkanTingkat kesesuaian wisata bahari berada pada nilai IKW untuk wisata pantai kategori sangat sesuai, wisata selam kategori sesuai, dan wisata snorkeling kategori sesuai bersyarat. Daya dukung kawasan (DDK) pada setiap kegiatan wisata yaitu wisata pantai 101 orang/hari, wisata selam 123 orang/hari dan wisata snorkeling disarankan perlu adanya rehabilitasi terlebih dahulu. Persepsi masyarakat terhadap pengelolaan dan pengembangan wisata bahari terutama dalam aspek ekologi, ekonomi dan sosial budaya masyarakat setempat. 
Yuwanda Ilham, Vol 46. No.2. Juli (2018) Hal. 1 - 10

\section{PENDAHULUAN}

Taman Wisata Perairan

Kepulauan Anambas dan laut sekitarnya merupakan salah satu kawasan konservasi perairan nasional yang dikelola oleh Kementerian Kelautan dan Perikanan melalui UPT Loka Kawasan Konservasi Perairan Nasional Pekanbaru berdasarkan Keputusan Menteri KP Nomor 37/KEPMEN-KP/2014 (Loka KKPN, 2014). Pengembangan konsep wisata di Taman Wisata Perairan Kepulauan Anambas mempunyai peran yang cukup penting dalam pengembangan sektor pariwisata, hal ini dikarenakan memiliki potensi kekayaan alam laut dan keindahan yang cukup menarik untuk dikembang sebagai obyek wisata.

Pulau Mangkian terletak di Desa Batu Belah, Kecamatan Siantan Timur daerah tersebut merupakan salah satu contoh desa yang akan dikembangkan sebagai desa percontohan wisata bahari dan termasuk dalam kawasan zona pemanfaatan pariwisata yang masuk dalam Rencana Pengelolaan dan Zonasi di Kawasan Taman Wisata Perairan Kepulauan Anambas dan Laut Sekitarnya (Loka KKPN, 2014). Pulau Mangkian merupakan bagian dalam pengembangan wisata bahari yang dianggap penting sebagai contoh desain pengelolaan yang ramah lingkungan, agar mencegah terjadi degradasi lingkungan. Dalam perkembangannya saat ini permasalahan dalam pengelolaan wisata bahari belum adanya toleransi terhadap lingkungan, terutama kepada pemanfaatan untuk mencari keuntungan. Oleh karena itu perlu ada kajian khusus terkait pemanfaatan yang optimal di daerah wisata.

Dalam peran pemanfaatan wisata bahari perlu ada kajian tentang pengelolaan dan pemanfaatan suatu pulau untuk dijadikan kawasan wisata bahari terutama di Pulau Mangkian. Pengaruh kesesuaian dan daya dukung (carrying capacity) dalam pengelolaan dan pemanfaatan merupakan adalah salah peran untuk menilai dampak dari pemanfaatan wisata terutama wisata bahari. Kajian tentang kesesuaian dan daya dukung merupakan konsep pendekatan alam melalui batas maksimum untuk menerima aktivitas yang dilakukan oleh manusia dalam kurun waktu tertentu, oleh karena itu penelitian tentang kesesuaian dan daya dukung perlu dilakukan di kawasan Pulau Mangkian dan sekitarnya.

\section{METODE PENELITIAN \\ Lokasi dan Waktu Penelitian}

Penelitian ini telah dilaksanakan pada Juli - September 2017 bertempat di Pulau Mangkian, Desa Batu Belah, Kecamatan Siantan Timur, Kabupaten Kepulauan Anambas, Provinsi Kepulauan Riau di Kawasan Taman Wisata Perairan Kepulauan Anambas.

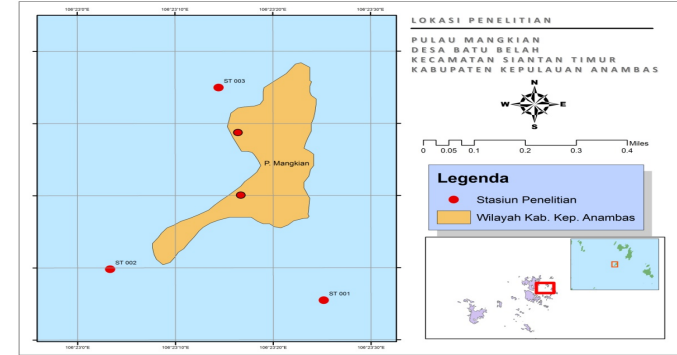

Gambar 1. Peta Lokasi Penelitian

\section{Parameter Kualitas Perairan}

Parameter kualitas perairan mempunyai peranan penting untuk pengelolaan wisata bahari karena faktor penting untuk menentukan suatu lingkungan perairan layak atau tidaknya dijadikan kawasan wisata untuk dikelola dan dikembangkan. Parameter kualitas perairan yang diukur dalam penelitian ini yaitu salinitas, suhu, $\mathrm{pH}$, kecerahan, kecepatan arus dan Dissolved Oxygen (DO).

\section{Terumbu Karang dan Ikan Karang}

Kondisi terumbu didasarkan pada nilai tutupan karang (persen cover), dengan menggunakan metode Underwater Photo Transect (UPT) 
dimana mengambil foto karang dengan menggunakan transek kuadran yang terbuat dari besi diameter $6 \mathrm{~mm}$ dengan ukuran $58 \times 44 \mathrm{~cm}^{2}$ (Giyanto et al., 2010 dalam P2O-LIPI, 2014). Hasil foto tersebut dianalisis dengan menggunakan aplikasi computer Coral Point Count wit Excel extension (CPCe) dan hasil dari gambar tersebut dianalisis kemudian di impor ke dalam format xls (excel) yang terlihat pada Gambar 2, yang dikembangkan oleh National Coral Reef Institute NOVA South Eastern University Oceanographic Center dalam P2O-LIPI (2014). Penilaian kondisi ekosistem terumbu karang ditentukan berdasarkan persen tutupan karang batu hidup dengan kriteria CRITC-COREMAP LIPI berdasarkan Gomez dan Yap (1988) dalam P2O-LIPI (2014), yaitu: 1) Kategori "Sangat baik" jika persentasenya adalah $75 \%-100 \%$; 2) Kategori "Baik" jika persentasenya 50\%$74,9 \%$; 3) Kategori "Sedang" jika persentasenya $25 \%-49,9 \%$; dan 4) Kategori "Buruk" jika persentasenya 0\%$24,9 \%$.
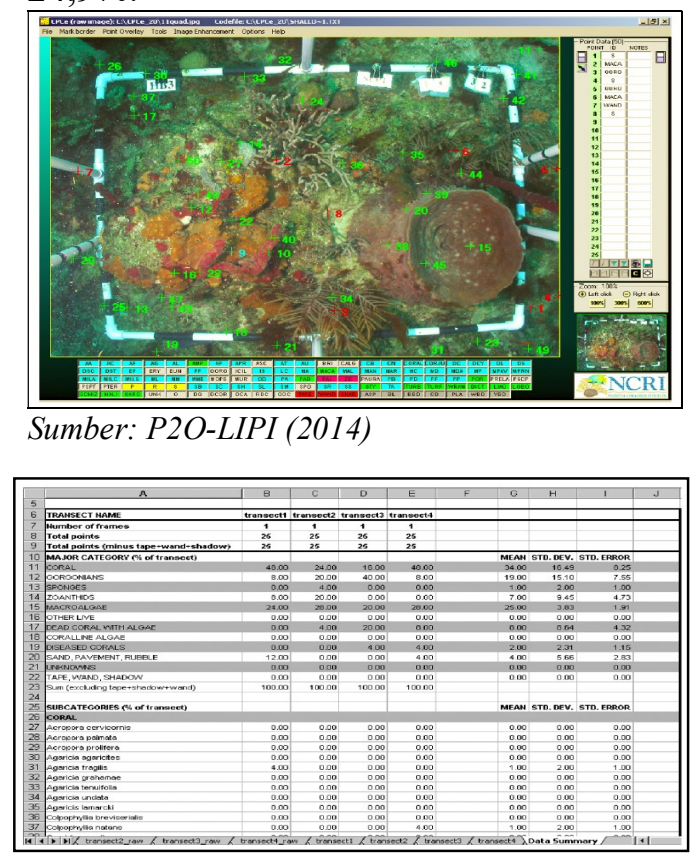

Gambar 2. Tampilan Layar CPCe dan Layar Data xls CPCe

Pengambilan data ikan karang menggunakan metode Underwater Visual Census (UVC) (English et al., 1997), dimana ikan-ikan yang dijumpai pada jarak 2,5 m di sebelah kiri dan kanan garis transek sepanjang $70 \mathrm{~m}$ dicatat jenis dan jumlahnya (Gambar 3).

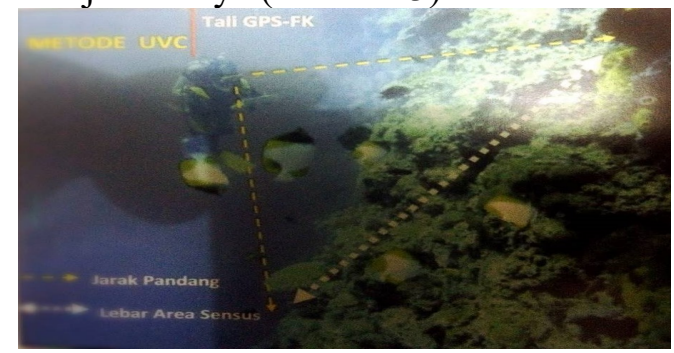

Gambar 3. Teknik Pengamatan Ikan dengan Metode UVC

Dalam menganalisa kelimpahan ikan karang dengan cara menghitung kelimpahan (ind. ha ${ }^{-1}$ ) pada setiap stasiun lokasi, dihitung persamaan berikut:

$$
\text { Kelimpahan }=\sum S i \times A
$$

Keterangan:

$\mathrm{Si}=$ Jumlah individu spesies ikan karang ke-i

A $=$ Nilai konversi luasan transek

(hektar)

\section{Kemiringan Pantai}

Kemiringan pantai dilakukan untuk mengetahui data kedalaman dan kemiringan pantai digunakan untuk menentukan jenis kegiatan wisata yang dapat digunakan. Pengukuran kemiringan pantai membandingkan jarak antara vegetasi sebagai batas daratan hingga bibir pantai sebagai batas lautan. Untuk menghitung kemiringan pantai berpedoman pada Mardiatno dalam Jasman (2013) yaitu:

$$
K=\frac{C}{L} x 100 \%
$$

\section{Keterangan :}

$\mathrm{K}=$ Kemiringan Pantai

$\mathrm{C}=$ Kedalaman

$\mathrm{L}=$ Jarak dari pantai ke arah laut (sejauh 30-50

m) dari pasang tertinggi.

Dengan demikian jika nilai $\mathrm{K}$ :

$0-2 \%=$ Datar

$>2-8 \%=$ Landai

$>8-30 \%=$ Miring

$>30-50 \%=$ Terjal

$>50 \%=$ Sangat terjal 
Yuwanda Ilham, Vol 46. No.2. Juli (2018) Hal. 1 - 10

Analisis Kesesuaian Wisata

Analisis ini digunakan mendapatkan data penentu beberapa syarat yang ditentukan dalam kegiatan wisata yang sesuai dengan objek wisata yang akan dikembangkan dengan melihat aspek ekologis lingkungan laut. Suatu kegiatan pemanfaatan yang akan dikembangkan hendaknya disesuaikan dengan potensi sumberdaya dan peruntukkannya. Setiap kegiatan wisata mempunyai persyaratan sumberdaya dan lingkungan yang sesuai dengan objek wisata yang akan dikembangkan. Untuk menghitung kesesuaian wisata menggunakan rumus (Yulianda, 2007).

Keterangan:

$$
\lrcorner \mathrm{KW}=\sum^{\prime}\left(\frac{\mathrm{N} 1}{\mathrm{Nmax}}\right) \times 100 \%
$$

IKW = Indeks kesesuaian wisata

$\mathrm{Ni} \quad=$ Nilai parameter ke-i (bobot $\mathrm{x}$ skor)

Nmax =Nilai maksimum dari suatu kategori wisata

Penentuan kesesuaian kawasan dilihat berdasarlan persentae kesesuaian, yang diperoleh perbandingan antara jumlah nilai dari seluruh parameter sesuai pengamatan dilapangan. Berikut beberapa matriks kesesuaian area yang peneliti analisis yaitu wisata selam pada Tabel 1, wisata snorkeling pada Tabel 2 dan wisata pantai pada Tabel 3 .

Tabel 1. Matriks Kesesuaian Area untuk Wisata Selam

\begin{tabular}{|c|c|c|c|c|c|c|c|c|c|}
\hline & Parameter & Boblot & $\$ S$ & \$loo: & 8 & Skon: $\quad S B$ & Skan! & & \\
\hline 1. & Recerthan $(\%)$ & s & 80 & 3 & 30.80 & $2 \quad 20.50$ & & 20 & 0 \\
\hline 2. & Tutupun Kardy & j & 715 & 3 & 80.73 & $1 \quad 25.50$ & & 85 & 0 \\
\hline 3. & Jenilififtom & 3 & "n & 3 & 412 & $\begin{array}{ll}2 & 4.7\end{array}$ & & 4 & 0 \\
\hline 4 & Jensilknk kaang & 3 & 3100 & 3 & 50.100 & $2 \quad 20.60$ & & 0 & 0 \\
\hline f & $\operatorname{Kecc}$. Ans (montit) & 1 & 0.15 & 3 & 815.30 & $\begin{array}{lll}2 & 300.50\end{array}$ & & & 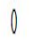 \\
\hline 6 & $\begin{array}{l}\text { Reddinnaterumbu } \\
\text { karange }\end{array}$ & 1 & 6.15 & f & 815.21 & $2 \quad 30130$ & & 30 & 0 \\
\hline
\end{tabular}

Sumber: Yulianda (2007)

Keterangan:

Kategori SS= Sangat Sesuai, dengan nilai IKW= $83-100 \%$.
Kategori $\mathrm{S}=$ Sesuai, dengan nilai IKW= $50-<$

$83 \%$.

Kategori SB = Sesuai Bersyarat, denga nilai IKW

$=17-<50 \%$

Kategori TS $=$ Tidak Sesuai, dengan nilai IKW $<$ $17 \%$

Tabel 2. Matriks Kesesuaian Area untuk Wisata Snorkeling

\begin{tabular}{|c|c|c|c|c|c|c|c|c|c|c|}
\hline Io & Parameter & Bobot & $\$ S$ & Skon" & 8 & Skon & $B B$ & Skor & TS & Skon \\
\hline 1 & Kecerahan $(\%)$ & 5 & 100 & 3 & 81.400 & 2 & 2060 & 1 & 40 & 0 \\
\hline 2. & Tutwan Karageg ( $(\%)$ & 5 & $3 / 5$ & 3 & 30.75 & 2 & 2660 & 1 & 28 & 0 \\
\hline 3. & Jenis life fom & 3 & $\$ 12$ & 3 & $0 \cdot 12$ & 2 & 4.7 & 1 & 4 & 0 \\
\hline 4. & Jemisikan karang & 3 & 30 & 3 & 30.50 & 2 & 10630 & 1 & 40 & 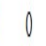 \\
\hline 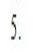 & $\operatorname{Kec}$ Anss (cm dit) & 1 & 0.15 & 3 & 215.30 & 2 & $30: 0$ & 1 & 30 & 0 \\
\hline 6. & $\begin{array}{l}\text { Kedalaman terumbu } \\
\text { karang }\end{array}$ & 1 & 1.3 & 3 & 3.6 & 2 & $: 0 \cdot 10$ & 1 & $\measuredangle 10$ & 0 \\
\hline ?. & $\begin{array}{l}\text { Lebarhamparan } \\
\text { dasarkatang (II) }\end{array}$ & 1 & 500 & 3 & $\begin{array}{l}3100 . \\
500\end{array}$ & 2 & $20 \cdot 100$ & 1 & 80 & 0 \\
\hline
\end{tabular}

Keterangan:

Kategori SS Sangat Sesuai, dengan nilai IKW

$=83-100 \%$.

Kategori $\mathrm{S}=$ Sesuai, dengan nilai IKW

$=50-<83 \%$,

Kategori SB = Sesuai Bersyarat, denga nilai IKW

$=17-<50 \%$

Kategori $\mathrm{TS}=$ Tidak Sesuai, dengan nilai IKW $<$ $17 \%$

Tabel 3. Wisata Pantai

\begin{tabular}{|c|c|c|c|c|}
\hline $\begin{array}{l}\mathrm{N} \\
\mathrm{o}\end{array}$ & Parameter & $\begin{array}{c}\text { Bo } \\
\text { bo } \\
\mathrm{t}\end{array}$ & Kategori & $\begin{array}{l}\mathrm{S} \\
\mathrm{k} \\
\text { or }\end{array}$ \\
\hline 1 & $\begin{array}{l}\text { Kedalaman peraira } \\
\text { (m) }\end{array}$ & 5 & $\begin{array}{c}0-3 \mathrm{~m} \\
>3-6 \mathrm{~m} \\
>6-10 \mathrm{~m} \\
>10 \mathrm{~m} \\
\end{array}$ & $\begin{array}{l}4 \\
3 \\
2 \\
1\end{array}$ \\
\hline 2 & Tipe pantai & 5 & $\begin{array}{c}\text { Pasir putih } \\
\text { Pasir putih, sedikit } \\
\text { karang } \\
\text { Pasir hitam, } \\
\text { berkarang, sedikit } \\
\text { terjal } \\
\text { Lumpur, berbatu, } \\
\text { terjal }\end{array}$ & 2 \\
\hline 3 & Lebar pantai (m) & 5 & $\begin{array}{c}>15 \\
10--15 \\
3-<10 \\
<3\end{array}$ & $\begin{array}{l}4 \\
3 \\
2 \\
1\end{array}$ \\
\hline 4 & $\begin{array}{l}\text { Material dasar } \\
\text { perairan }\end{array}$ & 4 & $\begin{array}{c}\text { Pasir } \\
\text { Karang berpasir } \\
\text { Pasir berlumpur } \\
\text { Lumpur }\end{array}$ & $\begin{array}{l}4 \\
3 \\
2 \\
1\end{array}$ \\
\hline 5 & $\begin{array}{l}\text { Kecepatan arus } \\
(\mathrm{m} / \mathrm{dt})\end{array}$ & 4 & $\begin{array}{c}0-0,17 \\
0,17-0,34\end{array}$ & $\begin{array}{l}4 \\
3\end{array}$ \\
\hline
\end{tabular}


Yuwanda Ilham, Vol 46. No.2. Juli (2018) Hal. 1 - 10

\begin{tabular}{|c|c|c|c|c|}
\hline \multirow[t]{3}{*}{$\begin{array}{l}\mathrm{N} \\
\mathrm{o}\end{array}$} & Parameter & $\begin{array}{c}\text { Bo } \\
\text { bo } \\
t\end{array}$ & Kategori & $\begin{array}{l}\mathrm{S} \\
\mathrm{k} \\
\text { or }\end{array}$ \\
\hline & & & $0,34-0,51$ & 2 \\
\hline & & & $>0,51$ & 1 \\
\hline \multirow{4}{*}{6} & \multirow{4}{*}{$\begin{array}{l}\text { Kemiringan } \\
\text { pantai }(0)\end{array}$} & \multirow{4}{*}{4} & $<10$ & 4 \\
\hline & & & $10 \_-25$ & 3 \\
\hline & & & $>2 \overline{5}-45$ & 2 \\
\hline & & & $>45$ & 1 \\
\hline \multirow{4}{*}{7} & \multirow{4}{*}{$\begin{array}{l}\text { Kecerahan } \\
\text { perairan }(\%)\end{array}$} & \multirow{4}{*}{3} & $>80$ & 4 \\
\hline & & & $>50-80$ & 3 \\
\hline & & & $20-50$ & 2 \\
\hline & & & $<20$ & 1 \\
\hline \multirow{4}{*}{8} & \multirow{4}{*}{$\begin{array}{l}\text { Penutupan lahan } \\
\text { pantai }\end{array}$} & \multirow{4}{*}{3} & $\begin{array}{c}\text { Kelapa, lahan } \\
\text { terbuka }\end{array}$ & 4 \\
\hline & & & $\begin{array}{l}\text { Semak, belukar, } \\
\text { rendah, savana }\end{array}$ & 3 \\
\hline & & & Belukar tinggi & 2 \\
\hline & & & $\begin{array}{c}\text { Hutan bakau, } \\
\text { pemukiman, } \\
\text { pelabuhan }\end{array}$ & 1 \\
\hline \multirow{4}{*}{9} & \multirow{4}{*}{ Biota berbahaya } & \multirow{4}{*}{3} & Tidak ada & 4 \\
\hline & & & Bulu babi & 3 \\
\hline & & & $\begin{array}{c}\text { Bulu babi, ikan } \\
\text { pari }\end{array}$ & 2 \\
\hline & & & $\begin{array}{c}\text { Bulu babi, ikan } \\
\text { pari, lepu, hiu }\end{array}$ & 1 \\
\hline \multirow{4}{*}{$\begin{array}{l}1 \\
0\end{array}$} & \multirow{4}{*}{$\begin{array}{l}\text { Ketersediaan air } \\
\text { tawar (jarak } / \mathrm{km} \text { ) }\end{array}$} & \multirow{4}{*}{3} & $<0.5(\mathrm{~km})$ & 4 \\
\hline & & & $>0.5-1(\mathrm{~km})$ & 3 \\
\hline & & & $>1-2(\mathrm{~km})$ & 2 \\
\hline & & & $>2(\mathrm{~km})$ & 1 \\
\hline
\end{tabular}

Sumber: Yulianda (2007)

Keterangan:

Kategori SS Sangat Sesuai, dengan nilai IKW= 83 $-100 \%$.

Kategori $\mathrm{S}=$ Sesuai, dengan nilai IKW= $50-<$ $83 \%$,

Kategori TS $=$ Tidak Sesuai, dengan nilai IKW $<$ $17 \%$

\section{Analisis Daya Dukung Kawasan}

Analisa daya dukung dihitung agar diketahui jumlah maksimum pengunjung yang secara fisik dapat ditampung di kawasan yang tersedia pada waktu tertentu tanpa menimbulkan gangguan pada alam dan manusia. Perhitungan Daya Dukung Kawasan (DDK) tersebut dapat dilihat dalam persamaan berikut (Yulianda, 2007):

Keterangan :

$$
\mathrm{DDK}=\mathrm{K} \times \frac{\mathrm{Lp}}{\mathrm{Lt}} \times \frac{\mathrm{Wt}}{\mathrm{Wp}}
$$

DDK : Daya dukung kawasan

$\mathrm{K}$ : Potensi ekologis pengunjung atau kapal per satuan unit area

Lp : Luas area atau panjang area yang dapat dimanfaatkan

Lt : Luas unit area untuk kebutuhan tertentu
Wt : Waktu yang disediakan oleh kawasan untuk kegiatan wisata dalam satu hari

Wp : Waktu yang dihabiskan pengunjung atau kapal untuk tiap kegiatan tertentu.Potensi ekologis pengunjung per satuan unit area dan unit area untuk kategori tertentu dapat dilihat pada Tabel 4.

Tabel 4. Potensi Ekologis Pengunjung (K) dan Luas Area Kegiatan (Lt)

\begin{tabular}{|c|c|c|c|c|}
\hline No & $\begin{array}{c}\text { Jenis } \\
\text { Kegiata } \\
n\end{array}$ & $\underset{\text { (orang) }}{\sum \mathrm{K}}$ & $\begin{array}{c}\text { Unit Area } \\
\text { (Lt) }\end{array}$ & Ket \\
\hline 1. & $\begin{array}{l}\text { Wisata } \\
\text { pantai }\end{array}$ & 1 & $50 \mathrm{~m}^{2}$ & $\begin{array}{c}1 \text { orang } \\
\text { setiap } 50 \\
\text { m panjang } \\
\text { pantai }\end{array}$ \\
\hline 2. & Snorkling & 1 & $500 \mathrm{~m}^{2}$ & $\begin{array}{l}\text { Setiap } 1 \\
\text { orang } \\
\text { dalam } 100 \\
\text { x } 5 \mathrm{~m}\end{array}$ \\
\hline 3. & Selam & 2 & $2.000 \mathrm{~m}^{2}$ & $\begin{array}{c}\text { Setiap } 2 \\
\text { orang } \\
\text { dalam } 200 \\
\times 10 \mathrm{~m}\end{array}$ \\
\hline
\end{tabular}

Sumber: Yulianda (2007)

Ket. $\mathrm{K}=$ Pengunjung

Hasil analisis kesesuaian yang ada, dari kawasan yang sangat sesuai dan sesuai akan digunakan sebagai dasar penentuan daya dukung sebagai luas atau panjang area yang dimanfaatkan (Lp). Prediksi waktu yang dibutuhkan untuk setiap kegiatan wisata disajikan pada Tabel 5.

Tabel 5. Prediksi Waktu yang Dibutuhkan untuk Setiap Kegiatan

\begin{tabular}{rlcc}
\hline No & $\begin{array}{c}\text { Jenis } \\
\text { Kegiatan }\end{array}$ & $\begin{array}{c}\text { Waktu yang } \\
\text { dibutuhkan } \\
- \text { Wp (jam) }\end{array}$ & $\begin{array}{c}\text { Total } \\
\text { waktu 1 } \\
\text { hari }- \text { Wt } \\
\text { (jam) }\end{array}$ \\
\hline 1. & Wisata & 3 & 6 \\
2. & Snontai & 3 & 6 \\
3. & Selam & 2 & 8 \\
\hline
\end{tabular}

Sumber : Yulianda (2007)

Menurut PP No. 18 tahun 1994 tentang pengusahaan pariwisata alam di zona pemanfaatan taman nasional dan taman wisata alam yaitu $10 \%$ dari luas zona pemanfaatan, dimana nilai daya dukung kawasan untuk kegiatan wisata bahari dapat dilihat pada rumus:

$$
\mathrm{DDW}=0,1 \times \mathrm{DDK}
$$


Yuwanda Ilham, Vol 46. No.2. Juli (2018) Hal. 1 - 10

Keterangan :

DDW = daya dukung wisata (orang);

DDK = daya dukung kawasan (orang)

\section{Persepsi Masyarakat tentang Kegiatan Wisata Bahari}

Penilaian persepsi masyarakat terkait kegiatan wisata bahari dilakukan melalui wawancara terhadap masyarakat setempat. Responden yang diambil, dipilih secara acak kepada 25 orang di Desa Batu Belah, Kecamatan Siantan Timur.

\section{HASIL DAN PEMBAHASAN Kualitas Perairan}

Parameter kualitas perairan mempunyai peranan penting untuk pengelolaan wisata bahari karena faktor penting untuk menentukan suatu lingkungan perairan layak atau tidaknya dijadikan kawasan wisata untuk dikelola dan dikembangkan. Parameter kualitas perairan yang diukur antara lain salinitas, suhu, pH, kecerahan, kecepatan arus dan Dissolved Oxygen (DO). Hasil pengukuran kualitas perairan menunjukan bahwa salinitas perairan berkisar $32-33$ $\%$ o, suhu $29-30{ }^{\circ} \mathrm{C}$, pH $7-8$, kecerahan perairan $76-83 \%$, dan kecepatan arus $0,12-0,43 \mathrm{~m} /$ detik, DO 7,3 - 8,2 mg/L. Kemiringan pantai di sekitar lokasi penelitian berkisar antara 5,57 - 13,5\%. Parameter perairan dan bentuk pantai ini sangat menentukan dalam atraksi kegiatan wisata yang sesuai di Pulau Mangkian stasiun tersebut seperti memancing, selam, dan berenang. Berdasarkan pendapat Yulianda (2007), kondisi ekosistem terumbu karang merupakan salah satu faktor dalam menentukan kesesuaian suatu objek wisata. Ekosistem terumbu merupakan salah atraksi dan daya tarik utama dalam kegiatan wisata pesisir terutama dalam kondisi baik dan memiliki keanekaragaman hayati yang tinggi.

\section{Terumbu Karang}

Terkait dengan kondisi terumbu karang di lokasi penelitian memiliki hamparan karang keras dengan tipe coral branching dan encrusting yang termasuk dalam genus millepora $s p$ dan montipora $s p$, penelitian dilakukan pada kedalaman 7 meter. Kondisi karang keras (Hard Coral) terdiri dari dua kategori karang Acropora dan non-Acropora dengan ratarata persentase $9.77 \%$ dan $23.37 \%$. Persentase tutupan terumbu karang menunjukkan bahwa lokasi penelitian di Pulau Mangkian memiliki nilai persentase tutupan karang hidup berkisar $30,10-34,80 \%$, untuk nilai kesehatan karang tergolong dalam kriteria Sedang $(25-49.9 \%)$ berdasarkan kriteria penilaian kondisi terumbu karang (Gomez \& Yap, 1988 dalam P2O-LIPI, 2014), nilai persentasi tutupan terumbu karang pada lokasi penelitian dapat dilihat pada Gambar 4.

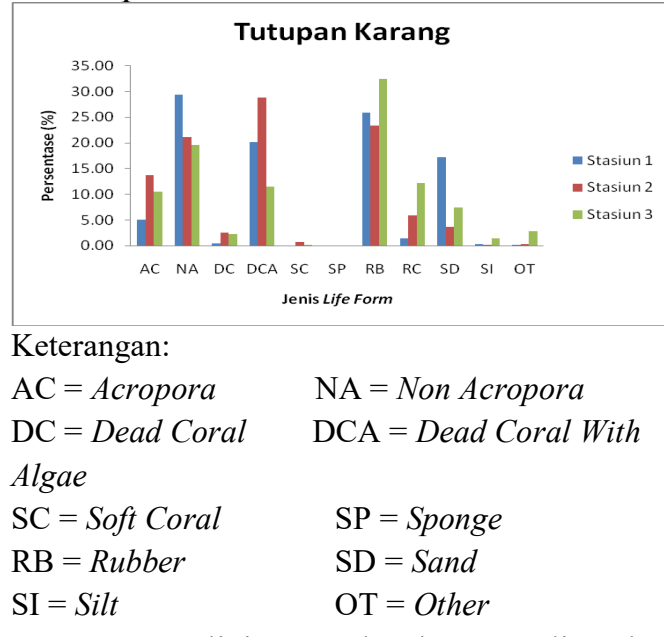

Kondisi terumbu karang di pulau Mangkian terletak jauh dari pemukiman penduduk desa Batu Belah dan desa lainnya. Berdasarkan data tutupan karang bahwa kondisi kerusakan karang cukup tinggi di Pulau Mangkian, terlihat dari persentase rata-rata $20,17 \%$ karang yang rusak akibatkan alga (DCA) dan 27, 27\% pecahan karang (RB), kondisi kerusakan karang ini sangat mempengaruhi pada jumlah ikan indikator. Kondisi tutupan karang yang terjadi diakibatkan oleh pengaruh perubahan iklim yang terjadi 
pada tahun 2016 yaitu el nino, dimana kondisi perairan laut di perairan Indonesia terkena dampak pemutihan karang (P2O-LIPI, 2016)

\section{Ikan Karang}

Pada hasil penelitian berikut tentang ikan karang di lokasi penelitian, dilakukan pengelompokan berdasarkan perannya menurut English, et al., (1997) yaitu ikan indikator (Corallivor), ikan herbivore, ikan ekonomis penting. Berdasarkan data hasil penelitian yang dijumpai 32 jenis dari 10 famili ikan karang yang ditemukan yaitu: Caesionidae, Chaetodontidae, Ephippidae, Kyphosidae, Labridae, Lutjanidae, Pomacanthidae, Scaridae, Serranidae, dan Siganidae. Rata-rata kelimpahan ikan dari seluruh pengamatan adalah 88,67 individu per $350 \mathrm{~m}^{2}$ atau setara dengan $2.371,42 \mathrm{ind} / \mathrm{ha}$.

\section{Jenis Biota Perairan}

Pulau Mangkian merupakan wilayah pulau berpantai yang memiliki sumberdaya pesisir yang cukup beragam rupa dan jenisnya. Biota perairan yang berpengaruh terhadap keselamatan dan keamanan pengunjung merupakan salah satu faktor yang mempengaruhi dalam kegiatan di suatu lokasi wisata. Dengan jumlah biota perairan yang berbahaya yang semakin sedikit membuat lokasi tersebut semakin baik. Berdasarkan pengamatan di lokasi penelitian dan juga wawancara terhadap masyarakat disekitar dan pengunjung, ditemukan beberapa jenis bulu babi pada kedalaman perairan sekitar 5 s.d 15 meter dengan jumlah tidak terlalu banyak, sehingga dapat disimpulkan bahwa lokasi tersebut aman untuk kegiatan di daratan sedangkan di dalam perairan cukup aman dan perlu berhati-hati.

\section{Tingkat Kesesuaian Wisata Bahari}

\section{Kesesuaian Wisata Selam}

Penentuan kesesuaian kawasan dilihat berdasarkan persentase kesesuaian wisata bahari yang disampaikan oleh Yulianda (2007) dimana dalam penentuan terkait dengan beberapa kegiatan wisata bahari yaitu kesesuaian area untuk wisata diving seperti kedalaman perairan, tutupan terumbu karang, jenis life form, jenis ikan karang, kecepatan arus, kedalaman terumbu karang serta tipe pantai. Tingkat kesesuaian wisata bahari dinilai dari kriteria penilaian kesesuaian wisata bahari yang dikemukan oleh Yulianda (2007), seperti kedalaman perairan, tutupan lamun, jenis lamun, serta tipe pantai (Tabel 6).

Tabel 6. Tingkat Kesesuaian Area Untuk Wisata Selam

\begin{tabular}{llccccccc}
\hline & & Bobo & \multicolumn{3}{c}{ Skor } & \multicolumn{3}{c}{ Ni (B x S) } \\
\cline { 5 - 8 } No. & Parameter & t & I & II & III & I & II & III \\
\hline 1 & Kecerahan & 5 & 3 & 2 & 2 & 1 & 10 & 10 \\
2 & $\begin{array}{l}\text { Tutupan } \\
\text { Karang }\end{array}$ & 5 & 1 & 1 & 1 & 5 & 5 & 5 \\
3 & $\begin{array}{l}\text { Jenis Life } \\
\text { Form }\end{array}$ & 3 & 3 & 3 & 3 & 9 & 9 & 9 \\
4 & $\begin{array}{l}\text { Jenis Ikan } \\
\text { Karang }\end{array}$ & 3 & 3 & 3 & 3 & 9 & 9 & 9 \\
& $\begin{array}{l}\text { Kecapatan } \\
\text { Arus } \\
\text { (cm/dt) }\end{array}$ & 1 & 3 & 1 & 2 & 3 & 1 & 2 \\
$\begin{array}{l}\text { Kedalaman } \\
\text { Perairan }\end{array}$ & 1 & 3 & 3 & 3 & 3 & 3 & 3
\end{tabular}

(m)

\begin{tabular}{|c|c|c|c|c|}
\hline & & 4 & & \\
\hline Total & & 4 & 37 & 38 \\
\hline IKW (\%) & & $\begin{array}{l}81, \\
48 \\
\end{array}$ & 68,52 & 70,37 \\
\hline $\begin{array}{c}\text { Tingkat } \\
\text { Kesesuaian }\end{array}$ & $\mathrm{S}$ & $\mathrm{S}$ & $\mathrm{S}$ & \\
\hline
\end{tabular}

Keterangan: IKW= Indeks Kesesuaian Wisata

Dari hasil penilaian kesesuaian area untuk wisata selam terhadap kawasan ekosistem terumbu karang di Pulau Mangkian dapat diketahui nilai indeks kesesuaian wisata di tiga lokasi pengamatan yakni Stasiun I, II, dan III memiliki nilai $68.52 \%-81.48 \%$ dengan kategori S (sesuai). Nilai atau kategori yang didapatkan ini, tentunya dipengaruhi oleh kondisi nyata di lapangan. Menurut pendapat peneliti terkait dengan kegiatan wisata selam diharapkan pada stasiun II untuk dimanfaatkan secara terbatas. Kelebihan dari pulau Mangkian memiliki hamparan terumbu karang di beberapa titik, dengan kondisi perairan jernih dan kedalamannya rata-rata $3 \quad-7$ meter, 
Yuwanda Ilham, Vol 46. No.2. Juli (2018) Hal. 1 - 10

sehingga sangat cocok untuk aktivitas wisata selam.

\section{Kesesuaian Wisata Snorkeling}

Kesesuaian untuk kegiatan wisata snorkeling memperhatikan penilaian terhadap beberapa parameter seperti kecerahan, tutupan terumbu karang, jenis life form, jenis ikan karang, kecepatan arus, kedalaman terumbu karang, dan lebar hamparan dasar karang (Tabel 7).

Tabel 7. Tingkat Kesesuaian Area untuk Wisata

\begin{tabular}{|c|c|c|c|c|c|c|c|c|}
\hline \multirow[t]{2}{*}{ No. } & \multirow[t]{2}{*}{ Parameter } & \multirow{2}{*}{$\begin{array}{l}\text { Bo } \\
\text { bot }\end{array}$} & \multicolumn{3}{|c|}{ Skor } & \multicolumn{2}{|c|}{$\begin{array}{r}\mathrm{Ni}(\mathrm{B} \\
\mathrm{S}) \\
\end{array}$} & $\mathrm{x}$ \\
\hline & & & I & II & III & I & II & III \\
\hline 1 & Kecerahan & 5 & 3 & 2 & 2 & 15 & 10 & 10 \\
\hline 2 & $\begin{array}{l}\text { Tutupan } \\
\text { Karang }\end{array}$ & 5 & 1 & 1 & 1 & 5 & 5 & 5 \\
\hline 3 & $\begin{array}{l}\text { Jenis Life } \\
\text { Form }\end{array}$ & 3 & 3 & 3 & 3 & 9 & 9 & 9 \\
\hline 4 & $\begin{array}{l}\text { Jenis Ikan } \\
\text { Karang }\end{array}$ & 2 & 3 & 3 & 3 & 6 & 6 & 6 \\
\hline 5 & $\begin{array}{l}\text { Kecapatan } \\
\text { Arus }(\mathrm{m} / \mathrm{dt})\end{array}$ & 1 & 3 & 1 & 2 & 3 & 1 & 2 \\
\hline 6 & $\begin{array}{l}\text { Kedalaman } \\
\text { Perairan (m) }\end{array}$ & 1 & 3 & 3 & 3 & 3 & 3 & 3 \\
\hline 7 & $\begin{array}{l}\text { Lebar } \\
\text { hamparan } \\
\text { dasar karang } \\
(\mathrm{m})\end{array}$ & 1 & 1 & 1 & 1 & 1 & 1 & 1 \\
\hline & Total & & & & & 27 & 25 & 26 \\
\hline & IKW (\%) & & & & & $\begin{array}{l}50, \\
00 \\
\end{array}$ & $\begin{array}{l}46, \\
30 \\
\end{array}$ & $\begin{array}{l}48, \\
15 \\
\end{array}$ \\
\hline & $\begin{array}{c}\text { Tingkat } \\
\text { Kesesuaiar }\end{array}$ & & & & & S & SB & SB \\
\hline
\end{tabular}

Dari hasil penilaian kesesuaian area untuk wisata snokeling terhadap kawasan ekosistem terumbu karang di pulau Mangkian dapat diketahui nilai indeks kesesuaian wisata di tiga lokasi pengamatan yakni Stasiun I, II, dan III memiliki nilai $46.30 \%-50.00 \%$ dengan kategori SB - S (sesuai bersyarat-sesuai). Nilai atau kategori yang didapatkan ini, tentunya dipengaruhi oleh kondisi nyata di lapangan. Kondisi ini diakibatkan persentasi tutupan karang yang rendah dengan luas hamparan dasar karang yang tidak terlalu luas lebih banyak hamparan pasir dan pecahan karang.

\section{Kesesuaian Wisata Pantai}

Kesesuaian untuk kegiatan wisata pantai memperhatikan penilaian terhadap beberapa parameter seperti kedalaman perairan, tipe pantai, lebar pantai, material dasar perairan, kecepatan arus, kemiringan pantai, kecerahan perairan, penutupan lahan pantai, biota berbahaya, dan ketersediaan air tawar (Tabel 8).

Tabel 8. Kesesuaian Wisata Pantai

\begin{tabular}{|c|c|c|c|c|c|c|}
\hline \multirow[t]{2}{*}{ No } & \multirow{2}{*}{ Parameter } & \multirow{2}{*}{$\begin{array}{c}\text { Bob } \\
\text { ot }\end{array}$} & \multirow{2}{*}{$\begin{array}{l}\text { Skor } \\
\text { IV } \\
\end{array}$} & \multicolumn{3}{|c|}{$\mathrm{Ni}(\mathrm{B} \times \mathrm{S})$} \\
\hline & & & & $\mathrm{V}$ & IV & $\mathrm{V}$ \\
\hline 1 & $\begin{array}{l}\text { Kedalama } \\
\text { n Perairan } \\
(\mathrm{m})\end{array}$ & 5 & 4 & 3 & 20 & 15 \\
\hline 2 & $\begin{array}{l}\text { Tipe } \\
\text { Pantai }\end{array}$ & 5 & 4 & 3 & 20 & 15 \\
\hline 3 & $\begin{array}{l}\text { Lebar } \\
\text { Pantai (m) }\end{array}$ & 5 & 4 & 2 & 20 & 10 \\
\hline 4 & $\begin{array}{l}\text { Material } \\
\text { dasar } \\
\text { perairan }\end{array}$ & 4 & 3 & 3 & 12 & 12 \\
\hline 5 & $\begin{array}{l}\text { Kecapatan } \\
\text { Arus } \\
(\mathrm{m} / \mathrm{dt})\end{array}$ & 4 & 4 & 4 & $\begin{array}{l}1 \\
6\end{array}$ & 16 \\
\hline 6 & $\begin{array}{l}\text { Kemiringa } \\
\text { n Pantai }\left({ }^{\circ}\right) \\
\text { Kecerahan }\end{array}$ & 4 & 4 & 3 & 16 & 12 \\
\hline 7 & $\begin{array}{l}\text { Perairan } \\
(\%)\end{array}$ & 3 & 4 & 4 & 12 & 12 \\
\hline 8 & $\begin{array}{l}\text { Penutupan } \\
\text { lahan } \\
\text { pantai }\end{array}$ & 3 & 3 & 3 & 9 & 9 \\
\hline 9 & $\begin{array}{l}\text { Biota } \\
\text { berbahaya }\end{array}$ & 3 & 3 & 3 & 9 & 9 \\
\hline 10 & $\begin{array}{l}\text { Kesediaan } \\
\text { air tawar } \\
\text { (jarak } / \mathrm{km} \text { ) }\end{array}$ & 3 & 3 & 2 & 9 & 6 \\
\hline & Total & & & & 143 & 116 \\
\hline & IKW (\%) & & & & 1.67 & $\begin{array}{c}74,3 \\
6 \\
\end{array}$ \\
\hline & $\begin{array}{c}\text { Tingkat } \\
\text { Kesesuaia } \\
\mathrm{n} \\
\end{array}$ & & & & SS & $\mathrm{S}$ \\
\hline
\end{tabular}

Dari hasil penilaian kesesuaian area untuk wisata pantai terhadap kawasan wisata bahari di pulau Mangkian dapat diketahui nilai indeks kesesuaian wisata di dua lokasi pengamatan yakni Stasiun IV dan V memiliki nilai 74.36 91.67 \% dengan kategori S - SS (sesuai dan sangat sesuai). Nilai atau kategori yang didapatkan ini, tentunya dipengaruhi oleh kondisi nyata di lapangan. Dimana kelebihan pulau Mangkian adalah memiliki hamparan pasir putih yang luas dan panjang, dengan kondisi perairan yang sangat jernih dan jauh dari pemukiman penduduk. 
Daya Dukung Kawasan Wisata Bahari

Daya dukung dapat diartikan seberapa maksimalnya pemanfaatan suatu kawasan atau ekosistem, terkait dengan aktifitas yang ada di dalam maupun di sekitar kawasan, untuk menghindari terjadi penurunan kualitas ataupun kemampuan ekologi suatu kawasan, baik terkait dengan keberlanjutan kondisi alami yang lestari. Daya dukung pemanfaatan didapatkan pada setiap kegiatan wisata berdasarkan luasan wilayah untuk kegiatan wisata pantai 25 , $23 \mathrm{Km}^{2}$ dan untuk luasan wilayah wisata snorkeling dan selam 306,692 $\mathrm{Km}^{2}$. Pada setiap daya dukung untuk kegiatan wisata memiliki jumlah yang berbeda, hal ini terlihat bahwa untuk kegiatan wisata pantai berjumlah 1.009 orang/hari. Sedangkan untuk kegiatan wisata snorkeling dan wisata selam berjumlah permasing-masing $\quad 1.227$ orang/hari (Tabel 9).

Tabel 9. Penilaian Daya Dukung Kawasan untuk Wisata Bahari

\begin{tabular}{clc}
\hline \multirow{2}{*}{ No. } & Jenis Kegiatan & $\begin{array}{c}\text { Daya Dukung } \\
\text { Pemanfaatan }\end{array}$ \\
\cline { 3 - 3 } & & Orang/hari \\
\hline 1 & Wisata Pantai & 1.009 \\
2 & Wisata Snorkeling & 1.227 \\
3 & Wisata Selam & 1.227 \\
\hline & Berdasarkan & pendapat Yuliand
\end{tabular}

Berdasarkan pendapat Yulianda (2007) berdasarkan PP No. 18/1994 tentang pengusahaan pariwisata alam di zona pemanfaatan pariwisata di taman wisata perairan, maka luas area yang dikembangkan adalah $10 \%$ dari luas zona pemanfaatan, oleh karena itu nilai DDK di kawasan konservasi perlu adanya batasan terkait dengan daya dukung pemanfaatan (DDP), nilai DDP di pulau Mangkian untuk masing-masing kegiatan wisata yaitu wisata pantai $101 \mathrm{orang} / \mathrm{hari}$, wisata selam 123 orang/hari dan wisata snorkeling 123 orang/hari dengan pemanfaatan terbatas.

\section{Persepsi Masyarakat Terhadap Wisata Bahari \\ Faktor penting dalam pengembangan wisata bahari yaitu}

masyarakat, oleh sebab itu perlu ada informasi tentang wisata bahari kepada masyarakat. Dari hasil wawancara dengan responden (masyarakat lokal) rata-rata menjawab tahu tentang istilah wisata bahari sebanyak $80 \%$ dan menjawab tahu $20 \%$. Hal ini dikarenakan telah adanya program terkait tentang pengaruh dari telah ditetapkannya Anambas sebagai Kawasan Taman Wisata Perairan yang dikelola oleh Kementerian Kelautan dan Perikanan dalam hal ini pengelolaan diserahkan kepada Loka Kawasan Konservasi Perairan Nasional (Loka KKPN) Pekanbaru bekerjasama dengan pemerintah Kabupaten Kepulauan Anambas.

Terkait dengan adanya pengembangan wisata bahari, masyarakat berdasarkan data responden yang di dapat setuju dengan persentase $100 \%$ untuk dikembangkan menjadi tujuan wisata bahari, dan ada beberapa rekomendasi tidak hanya di pulau Mangkian saja tetapi di pulau-pulau lain di sekitar desa Batu Belah terutama di kecamatan Siantan Timur, selain itu juga masyarakat berharap bisa terlibat langsung dalam kegiatan wisata bahari (100\%) dengan harapan wisata bahari yang akan dikembangkan ini harus menjaga kelestarian alam yang dimilikinya.

\section{KESIMPULAN}

Penelitian analisa kesesuaian dan daya dukung wisata bahari di Pulau Mangkian Taman Wisata Perairan Kepulauan Anambas dapat disimpulkan bahwa kondisi ekologis wisata bahari meliputi kualitas perairan, ekosistem terumbu karang dan ikan karang dan jenis biota perairan adalan baik. Tingkat kesesuaian wisata bahari daerah ini berada pada nilai IKW sangat sesuai untuk wisata pantai, sesuai untuk wisata selam, sesuai bersyarat untuk wisata snorkeling, Nilai daya dukung kawasan berdasarkan aktifitas wisata bahari antara lain wisata pantai sebanyak 101 orang/hari, wisata selam 123 orang/hari, 
Yuwanda Ilham, Vol 46. No.2. Juli (2018) Hal. 1 - 10

wisata snorkeling perlu adanya kegiatan rehabilitasi sebelum dimanfaatkan untuk kegiatan wisata. Sedangkan persepsi masyarakat terkait dengan pengembangan wisata bahari di daerah ini terutama dari peran serta masyarakat untuk terlibat dalam kegiatan wisata.

\section{SARAN}

Perlu adanya penelitian lanjutan terkait dengan dampak perubahan alam dari pemanfaatan wisata bahari terhadap sumber daya alam di Pulau Mangkian dan sekitarnya

\section{UCAPAN TERIMA KASIH}

Penelitian ini dilakukan dalam rangka penyelesaian tesis penulis. Penulis mengucapkan terima kasih kepada Loka KKPN Pekanbaru atas bantuan dan dukungan dalam penelitian ini sehingga telah selesai dengan baik. Ucapan terima kasih juga disampaikan kepada Pemerintah Kabupaten Kepulauan Anambas, Aparat Pemerintah dan Masyarakat Desa Batu Belah, Kecamatan Siantan Timur atas dukungan data dan informasi yang telah diberikan.

\section{DAFTAR ACUAN}

English, S., C. Wilkinson., V. Baker. 1994. Survey Manual for Tropical Marine Resources. Australian Institute of Marine Science. Townsville. 368 p.

Jasman. 2013. Strategi Pengembangan Ekowisata Bahari PulauPalambak Kabupaten Aceh Singkil Provinsi Nanggroe Aceh Darussalam (Skripsi). Pekanbaru: Program Sarjana Fakultas Perikanan dan Ilmu Kelautan Universitas Riau. 86 hal

Kementerian Lingkungan Hidup. 2004. Keputusan Menteri Lingkungan Hidup Nomor 51 Tahun 2004 Tentang Baku Mutu Air Laut Untuk Wisata Bahari. Menteri Lingkungan Hidup. Jakarta
Loka KKPN Pekanbaru. 2014. Rencana Pengelolaan dan Zonasi TWP Kepulauan Anambas dan Laut Sekitarnya. Ditjen PRL. KKP. Pekanbaru

P2O-LIPI. 2014. Pedoman Monitoring Kesehatan Terumbu Karang. Coremap- CTI. LIPI. Jakarta. 77 hal.

Yulianda, F. 2007. Ekowisata Bahari Sebagai Alternatif Pemanfaatan Sumberdaya Pesisir Berbasis Konservasi. Makalah Sains Departemen MSP. IPB. Bogor.

Yulianda, F., Siregar, V.P., Karlina, I., dan Johan, Y. 2011.Pengembangan Wisata Bahari Dalam Pengelolaan Sumberdaya Pulau-Pulau Kecil Berbasis Kesesuaian Dan Daya Dukung - Studi Kasus Pulau Subesi Provinsi Lampung.Seminar Nasional Pengembangan Pulau-Pulau Kecil dari Aspek Perikanan Kelautan dan Pertanian. IPB. Bogor. Hal 119 - 129.

\section{Email :}

Yuwan39psdp@gmail.com yikhwan@gmail.com deni_yasmin@yahoo.co.id 